\title{
KUALITAS PERNIKAHAN DAN STRES PENGASUHAN PADA ORANG TUA YANG MEMILIKI ANAK BERKEBUTUHAN KHUSUS
}

\author{
Moch. Aji Chandra Raharja, Siti Suminarti, Ari Firmanto
}

\begin{abstract}
* Corresponding Author: Email:

macraharja@gmail.com, fasikhahss@yahoo.com, arifirmanto2@gmail.com
\end{abstract}

Universitas Muhammadiyah Malang
Abstrak. Setiap orang tua dengan anak berkebutuhan khusus umumnya memiliki stres pengasuhan yang lebih tinggi dibandingkan orang tua dengan anak normal, karena anak berkebutuhan khusus sangat membutuhkan perhatian dan perlakuan khusus yang lebih. Salah satu faktor yang dapat mempengaruhi tingkat stres tersebut adalah kualitas pernikahan. Sepasang suami istri dengan pernikahan yang berkualitas akan memiliki komunikasi dan interaksi yang baik antar keduanya sehingga stres pengasuhan pun dapat menurun. Tujuan dari penelitian ini adalah untuk mengkaji tentang hubungan dari kedua variabel tersebut. Penelitian ini dilakukan dengan metode kuantitatif menggunakan teknik pengambilan data quota sampling dengan subjek berjumlah 80 orang tua yang memiliki anak berkebutuhan khusus. Subjek diukur menggunakan skala berjumlah 63 item yang dimodifikasi dari Parenting Stress Index (PSI) dan skala kualitas pernikahan milik Allendorf \& Ghimire (2013). Data dianalisa secara korelasional menggunakan product momment pearson. Hasil penelitian ini menunjukan bahwa kualitas pernikahan dan stres pengasuhan memiliki hubungan negatif yang signifikan dengan nilai $(\mathrm{r}=-293 ; \mathrm{p}=0.008)$, dimana saat orang tua memiliki kualitas pernikahan yang baik maka stres pengasuhannya akan semakin rendah. Selain itu, hasil penelitian ini diharapkan dapat menambah pengetahuan bagi para orang tua agar dapat menjaga kualitas pernikahan mereka guna meminimalisir stres pengasuhan yang dapat mereka alami.

Kata kunci: kualitas pernikahan, stres pengasuhan, orang tua yang memiliki ABK

Abstract. Level of parenting stress than parents with normal children, because children with special needs need more attention and special treatment. One of the factors that can affect stress levels is the quality of marriage. A couple of husband and wife with a quality marriage will have good communication and interaction between the two so that the stress of parenting can decrease. The purpose of this study is to examine the relationship of the two variables. This research was conducted with a quantitative method using quota sampling data with 80 subjects who had children with special needs. Subjects were measured using a scale of 63 items modified from the Parenting Stress Index (PSI) and the quality of the marriage scale of Allendorf \& Ghimire (2013). The data is analyzed correlatively using the momment Pearson product. The results of this study indicate that the quality of marriage and parenting stress have a significant negative relationship with the value ( $r=-293 ; p=0.008)$, where when parents have a good quality of marriage the stress of parenting will be lower. In addition, the results of this study are expected to increase knowledge for parents to be able to maintain the quality of their marriage in order to minimize the stress of parenting they can experience. Keywords: marital quality, parenting stress, parents who have children with special needs 


\section{PENDAHULUAN}

Setiap orang tua memiliki banyak tugas rumah tangga yang harus dikerjakan, termasuk mengasuh anak, dan kegiatan mengasuh anak biasanya dapat mendatangkan kebahagiaan tersendiri pada orang tua. Namun, tidak semua orang tua memiliki anak yang terlahir normal secara fisik maupun mental, adapun orang tua yang memiliki Anak Berkebutuhan Khusus (ABK), yaitu anak yang memiliki keterbatasan pada fisik, emosional, sosial, maupun mental-intelektual mereka. Dimana keterbatasan tersebut dapat secara signifikan mempengaruhi proses pertumbuhan atau perkembangan mereka, sehingga orang tua pun harus memberikan perlakuan dan fasilitas khusus yang paling berbeda dibandingkan anak-anak lain dengan usia yang sama pada umumnya (Winarsih, 2013).

Pada umumnya, orang tua yang memiliki anak dengan keterbatan pasti akan merasakan proses pengasuhan yang lebih berat dibandingkan dengan orang tua yang memiliki anak normal. Seperti hasil wawancara peneliti pada orang tua dari salah satu anak penderita spektrum autisme yang bersekolah di SD Islam Mohammad Hatta Lowokwaru Malang 25 Oktober 2018, dimana ia mengungkapkan bahwa memiliki anak dengan keterbatasan semacam itu membuatnya harus lebih sabar dan bersyukur kepada tuhan atas keadaan anak mereka terlebih dahulu, sehingga kemudian mereka dapat membuka pikiran dan belajar membiasakan diri untuk memberi perlakuan yang baik dan tepat pada sang anak.

Adapun kasus lain yang terjadi di kota Surabaya pada tahun 2015 lalu, dimana terdapat suami istri yang bercerai karena mereka memiliki anak berkebutuhan khusus dengan jenis $\mathrm{Au}-$ tis. Perceraian terjadi karena pihak suami merasa malu memiliki anak berkebutuhan khusus. Ditambah lagi, pihak suami dan istri tidak kompak dalam merawat sang anak. Mereka memiliki pandangan yang berbeda mengenai cara atau metode dalam membimbing anak mereka yang memiliki kebutuhan khusus, sehingga kemudian mereka pun mengalami stres pengasuhan dan memutuskan untuk bercerai (Pramudito, 2015).

Pernikahan merupakan sebuah perjanjian yang membuat pergaulan antara seorang pria dan wanita menjadi halal, namun juga menimbulkan hak dan kewajiban yang harus dilaksanakan oleh keduanya (Santoso, 2017).
Pernikahan dapat dikatakan sah apabila telah dilaksanakan menurut hukum pernikahan pada masing-masing agama dan kepercayaan, serta telah dicatatkan oleh lembaga yang berwenang sesuai perundang-undangan yang berlaku di negara pasangan tersebut (Firmansyah, Sukirno, \& Sudaryatmi, 2017).

Seperti masyarakat pada umumnya, setelah menikah biasanya sepasang suami dan istri akan memiliki seorang anak. Dengan kata lain, tanggung jawab mereka pun akan bertambah, yaitu menjadi orang tua dari anak-anak mereka. Orang tua memiliki peran penting dalam mendukung dan memenuhi kebutuhan sang anak demi terwujudnya kesejahteraan untuk anak mereka. Selain memenuhi kebutuhan, ada pun tugas lain dengan tantangan besar bagi orang tua di dalam sebuah keluarga, salah satunya adalah mengasuh anak (Soenens \& Deci, 2017).

Meski mendatangkan kebahagiaan dan kesenangan tersendiri, mengasuh anak juga sangat melelahkan dan mengandung banyak cobaan yang dapat menguji kesabaran serta memberikan beban pikiran pada orangtua yang menjalankannya. Cobaan-cobaan tersebut pun pastinya akan terasa lebih berat bila sang anak merupakan seorang Anak Berkebutuhan Khusus. Karena bila dibandingkan dengan anakanak normal pada umumnya, anak berkebutuhan khusus tentu membutuhkan perhatian yang lebih dan perlakuan yang berbeda sesuai dengan jenis kebutuhannya (Winarsih, 2013).

Namun pada kenyataannya tidak semua orang tua dapat secara cepat terbiasa dengan kondisi anak dan beradaptasi dengan kebiasaan memberi perlakuan-perlakuan khusus pada anak. Maka dari itulah tidak jarang dari mereka yang pada akhirnya mengalami stres pengasuhan. Seperti salah satu pendapat yang mengatakan bahwa membesarkan anak penyandang cacat lebih sulit bagi orang tua, dan beberapa kesulitan perkembangan yang sering dijumpai antara lain adalah keterbelakangan mental, gangguan spektrum autisme dan gangguan belajar khusus di antara yang lainnya (Sinha, Verma, \& Hershe, 2016).

Kesulitan perkembangan tersebut menyebabkan anak-anak ini sering tertinggal di belakang rekan-rekan mereka dalam mata pelajaran tertentu, dimana hal itu sangat memengaruhi akademisi dan kegiatan sehari-hari mereka, ditambah dengan adanya beban yang bersumber dari berbagai perilaku seperti hiperaktif atau 
semacamnya. Sehingga orangtua dari anak-anak tersebut mengalami kesulitan dalam menangani masalah-masalah yang berhubungan dengan pendidikan anak, terutama mengenai prestasi akademik anak yang buruk dan masa depan anak yang meragukan (Sinha et al., 2016).

Tidak hanya itu, orang tua tersebut juga akan menghabiskan sebagian besar waktu dan energi mereka untuk kebutuhan khusus sang anak. karena itulah mereka rentan mengalami stres pengasuhan yang hebat ketika beradaptasi dan belajar untuk merawat anak mereka sembari menerima stigma sosial dan sikap negatif dari orang sekitar terhadap anak mereka (Sinha et al., 2016). Stres pengasuhan sendiri merupakan kondisi dimana proses pengasuhan orang tua mengalami penurunan efektifitas dan kualitas yang ditandai dengan berkurangnya ucapan-ucapan yang mengandung afeksi dan kehangatan, tindakan pengasuhan yang kurang konsisten, orang tua memunculkan pernyataan permusuhan pada anak, dan meningkatnya kekerasan dalam hal mendisiplinkan anak (Deckard, 2004).

Stres pengasuhan juga melibatkan serangkaian proses kompleks dan dinamis yang berhubungan dengan beberapa hal, antara lain yaitu, anak dan perilakunya, tuntutan pengasuhan, sumber pengasuhan, reaksi fisiologis terhadap tuntutan pengasuhan, kualitas hubungan orang tua dengan anak dan anggota keluarga lainnya, serta hubungan dengan orang lain di luar rumah (Deckard, 2004). Terdapat salah satu tokoh yang mengemukakan pendapat bahwa stres pengasuhan yang dialami oleh orang tua dari Anak Berkebutuhan Khusus dapat dipengaruhi oleh beberapa faktor, diantaranya adalah dukungan sosial, tingkat religiusitas orang tua, tingkat kebutuhan atau keparahan anak, kondisi ekonomi, pemahaman orang tua mengenai kebutuhan anak, persepsi orang tua terhadap kondisi anak, dan kecemasan orang tua akan masa depan anak (Ilias, Cornish, Kummar, Park, \& Golden, 2018).

Namun dari beberapa faktor stres pengasuhan yang telah dijelaskan diatas, belum ada pemaparan secara khusus mengenai adanya keterkaitan antara stres pengasuhan pada orang tua dengan kualitas pernikahan yang dimiliki oleh orang tua. Padahal terdapat pendapat yang menyatakan bahwa durasi waktu perawatan anak yang dihabiskan bersama oleh sepasang suami istri dapat secara signifikan memediasi tekanan harian yang dirasakan oleh suami mau- pun istri tersebut (Harper \& Dyches, 2013). Dimana hal itu secara tidak langsung mengartikan bahwa kualitas hubungan ayah dan ibu memiliki kemungkinan untuk saling berkaitan dengan tingkat stres yang mereka alami saat menjalankan proses pengasuhan anak sehari-hari. Selaras dengan pendapat tersebut, ada pula pendapat yang menyatakan bahwa dinamika dalam hubungan pernikahan orang tua (ayah-ibu) dan hubungan orang tua-anak saling berhubungan dan saling bergantung (Christopher et al., 2015).

Adapun pendapat yang telah dijelaskan oleh beberapa ahli mengenai arti dari kualitas pernikahan dalam penelitian, salah satunya adalah pendapat yang mengatakan bahwa kualitas pernikahan merupakan ungkapan dari apa yang dirasakan oleh individu mengenai pernikahannya (Fowers \& Owens, 2010). Kualitas pernikahan dapat digambarkan dalam sepuluh bidang, yaitu: distres global, komunikasi afektif, komunikasi, penyelesaian masalah, waktu bersama, perselisihan tentang keuangan, ketidakpuasan seksual, orientasi peran, riwayat keluarga yang terkait dengan distres, ketidakpuasan dengan anak, dan konflik yang berkaitan dengan pengasuhan (Wahyuningsih, 2013).

Terdapat beberapa faktor yang mempengaruhi kualitas pernikahan, salah satu faktor utamanya adalah usia saat menikah. Usia saat menikah bisa saja merupakan faktor yang mendasar dalam kualitas pernikahan, karena kematangan usia saat menikah akan mempengaruhi proses pengambilan keputusan suami dan istri dalam menghadapi segala permasalahan yang dapat terjadi pada rumah tangga mereka. Pernyataan tersebut diperkuat oleh pendapat yang mengatakan bahwa usia saat menikah dapat menjadi faktor penting dan mendasar dalam menciptakan konsekuensi pernikahan yang ditentukan menurut keadaan lingkungan, ekonomi, dan budaya tertentu dalam masyarakat (Zaheri et al., 2016).

Sebagian besar penelitian mengacu pada rentang usia 18-25 dan 24-30 tahun sebagai usia pernikahan yang cocok untuk pria dan wanita, masing-masing karena beberapa percaya bahwa pernikahan pada usia ini disertai dengan kualitas hidup yang lebih tinggi dan pernikahan pada usia di bawah 18 tahun untuk wanita dan 20 untuk pria kemungkinan akan dikaitkan dengan perceraian atau kegagalan dan menurunnya stabilitas pernikahan. Dalam beberapa penelitian, itu menunjukkan bahwa individu yang menikah 
muda dan tua tidak puas dengan kehidupan pernikahan mereka. Namun, ketidakpuasan lebih tinggi di antara pasangan yang menikah muda (Zaheri et al., 2016).

Selain usia pernikahan, ada pula faktor penting lain yang mempengaruhi kualitas pernikahan pada sepasang suami istri, antara lain yaitu faktor demografi yang berfokus pada pendidikan pasangan, perbedaan usia, durasi pernikahan, pekerjaan pasangan suami-istri tersebut, keberadaan dan jumlah anak-anak, situasi ekonomi, dan perbedaan budaya antara kedua pasangan. Tidak terlepas dari hal-hal tersebut, adapun faktor jenis kelamin yang juga sangat berpengaruh pada kualitas hubungan sepasang suami istri, hal ini dikarenakan perbedaan jenis kelamin akan memunculkan pandangan yang berbeda pula (Zaheri et al., 2016).

Jenis kelamin memainkan peran penting dalam banyak aspek kehidupan dan hubungan antara seorang wanita dan pria. Perempuan dan laki-laki memiliki pandangan berbeda tentang kepuasan pernikahan. Dalam pandangan seorang perempuan, komunikasi, pemahaman, hubungan keluarga, kesepakatan, dan penghasilan oleh kedua pasangan merupakan faktor yang efektif dalam kepuasan pernikahan, sementara dalam pendapat pria, pendidikan pasangan, pendapatan oleh pasangan, pemahaman, kesepakatan, hubungan keluarga, dan komunikasi adalah faktor efektif dalam menciptakan kepuasan (Zaheri et al., 2016).

Adapun sebuah kasus yang secara tidak langsung menggambarkan bahwa kualitas pernikahan berkaitan dengan stres pengasuhan, yaitu hasil wawancara peneliti terhadap seorang ibu dari salah satu anak berkebutuhan khusus di SD Islam Mohammad Hatta Lowokwaru Malang pada 11 Oktober 2018. Dimana ia menyatakan bahwa kedekatannya dengan suami sangat membantu dirinya untuk bangkit dan melawan tekanan, baik dalam menghadapi lingkungan sosial maupun dalam menghadapi perilaku sang anak. Karena kehadiran suaminya tidak hanya berperan sebagai motivator dan penyemangat saja, namun juga bertindak aktif dalam membantu sang ibu merawat dan mengasuh anak di rumah. Selain itu, kehadiran sang ayah juga kerap menjadi sarana berbagi cerita dan keluh kesah oleh sang ibu atas lelahnya merawat si anak, sehingga tekanan sehari-sehari saat mengasuh anak dapat menurun.

Sejalan dengan kasus diatas, adapun pendapat yang mengatakan bahwa kesejahteraan emosional dari satu pasangan dalam hubungan keluarga dapat mempengaruhi komponen yang lain dalam keluarga, hal itu terjadi karena adanya transfer emosi atau stres dari satu orang ke orang lain. Emosi negatif dari salah satu pasangan memiliki kemungkinan negatif mempengaruhi pasangan lain yang dapat mengganggu hubungan mereka, hingga akhirnya permasalahan dapat mengarah ke dalam fungsi keseluruhan keluarga (Mitchell, Szczerepa, \& Hauser-cram, 2016).

Berdasarkan beberapa penjelasan diatas, dapat dikatakan bahwa kualitas pernikahan yang salah satunya ditandai dengan terjalinnya hubungan dan komunikasi yang baik pula antara suami dan istri tersebut bisa saja memiliki hubungan yang saling berkaitan dengan tingginya stres pengasuhan pada orang tua dengan anak berkebutuhan khusus. Sayangnya hubungan tersebut belum pernah dikaji secara khusus untuk melihat secara jelas mengenai bagaimana kedua variabel saling berkaitan.

Ditinjau dari pentingnya kajian tentang hubungan kualitas pernikahan dengan stres pengasuhan pada orang tua dengan anak berkebutuhan khusus, penulis ingin melakukan penelitian mengenai hubungan dari kedua variabel tersebut. Penelitian ini bertujuan untuk menggali kajian dan membuktikan apakah terdapat hubungan antara kualitas pernikahan dengan stres pengasuhan pada orang tua dari anak-anak berkebutuhan khusus, karena belum ada penelitian terdahulu yang secara langsung mengkaji tentang hubungan dari dua variabel tersebut. Selain itu, hasil penelitian ini juga diharapkan dapat dimanfaatkan sebagai pengetahuan yang baru bagi para orang tua untuk digunakan dalam proses pengasuhan anak sehari-hari.

\section{Stres Pengasuhan}

Stres pengasuhan merupakan sebuah keadaan dimana terdapat proses yang menyebabkan timbulnya reaksi fisiologis dan kondisi psikologis yang tidak disenangi sebagai bentuk dari proses adaptasi dengan tuntutan peran dalam menjalankan tugas sebagai orang tua. Sehingga kemudian dapat menimbulkan ketegangan serta kecemasan berlebihan yang berasal dari interaksi dan peran pengasuhan anak yang sedang dijalankan oleh orang tua (Deckard, 2004). Dalam penelitian lain, Deater-Deckard juga menambahkan bahwa stres pengasuhan 
adalah stres yang muncul bersamaan dengan adanya persepsi bahwa sumber daya atau kemampuan orangtua dalam mengasuh anaknya tidak mencukupi untuk memenuhi tuntutan peran pengasuhan (Theule, 2018).

Sedangkan teori lain dalam model ABCX mengatakan bahwa Stres pengasuhan adalah stres yang disebabkan oleh tuntutan anak dan sumber daya eksternal ataupun internal yang kurang. Tuntutan dari anak yang dimaksud disini meliputi IQ dan kemampuan berbahasa yang rendah, penyimpangan perilaku yang menimbulkan masalah, perilaku adaptif, dan keparahan dari kelainan sang anak. Adapun penyebab lain yang bersumber dari karakteristik keluarga, yaitu mencakup jumlah anak dan kondisi keluarga yang ada di rumah. Penyebab internal dapat bersumber dari rendahnya tingkat pendidikan orang tua maupun pendapatan keluarga pertahun dan juga ras dari orang tua. Sedangkan sumber eksternal dapat disebabkan oleh layanan psikologi untuk anak yang kurang memadai, kurangnya konsultasi, intervensi, ataupun kerjasama dari orangtua dan guru (Krakovich, Mcgrew, Yu, \& Ruble, 2016).

Sedangkan menurut Abidin (1995), Stres pengasuhan adalah stres yang bersumber dari gabungan kompleks yang mengaitkan tiga faktor, yaitu anak, orang tua, dan interaksi (anakorang tua). Stres pengasuhan juga diartikan sebagai perasaan cemas dan tegang melebihi batas yang akhirnya berimbas pada peran orang tua beserta interaksinya dengan anak. Dalam penelitian lain, Abidin menambahkan bahwa stres pengasuhan adalah hasil penilaian dari setiap orang tua mengenai tingkat komitmen mereka terhadap peran pengasuhan (Abidin, 2010).

Ditinjau dari pernyataan di atas, dapat dikatakan bahwa stres pengasuhan merupakan keadaan dimana seorang ibu atau ayah mengalami kendala pengasuhan akibat rasa kurang berdaya dalam menjalankan tugas sebagai orang tua sehingga menimbulkan rasa cemas yang berlebihan dan menyebabkan proses pengasuhan anak menjadi berjalan dengan tidak efektif.

Berdasarkan beberapa pengertian tentang stres pengasuhan yang telah dijelaskan diatas, peneliti memilih menggunakan teori stres pengasuhan menurut Abidin (1995) sebagai acuan dalam penelitian ini, karena pendapat yang dikemukakan merupakan teori dasar dan utama yang membahas tentang stres pengasuhan.

Menurut Johnston et al. (2003), terdapat beberapa faktor yang mempengaruhi stres pengasuhan pada orang tua, antara lain, Child behavioral problems (bagian yang bermasalah dari perilaku anak), Family cohesion (tanggung jawab dan interpersonal support di dalam keluarga), Family income (status social economi yang juga berkaitan dengan support dan kemampuan problem solving sebagai coping strategy dalam keluarga), dan Maternal psychological well being (kesejahteraan psikis).

Adapun pendapat yang mengatakan bahwa stres orang tua yang dialami selama proses pengasuhan anak-anak disabilitas dapat dipengaruhi oleh beberapa faktor utama, seperti, dukungan orang tua terhadap keluarga, perilaku pada anak, dan kemampuan coping stres orang tua (Hsiao, 2017).

Tidak hanya itu, pendapat lain menyebutkan bahwa stres pengasuhan yang dialami oleh para orang tua dengan anak berkebutuhan khusus dapat dipengaruhi oleh beberapa faktor, antara lain, tingkat religiusitas, dukungan sosial dari orang-orang sekitar, tingkat keparahan dari keterbatasan yang dialami sang anak, status ekonomi atau finansial dari orang tua itu sendiri, persepsi dan pemahaman orang tua tentang jenis keterbatasan atau kebutuhan sang anak, serta kecemasan dan ketakutan orang tua terhadap masa depan sang anak (Ilias et al., 2018).

Terdapat beberapa aspek dari stres pengasuhan menurut Abidin (1995) diantaranya adalah stress pengasuhan yang bersumber dari orang tua itu sendiri (Parent Domain) yang meliputi (1) restriction imposed by parent role (perasaan ditekan oleh kebutuhan dan permintaan anak), (2) Social Isolation (perasaan terisolasi dan jauh dari dukungan sosial), (3) Feeling of competence (perasaan memiliki kemampuan mengasuh anak yang kurang), (4) relationship with spouse (kurangnya dukungan emosional dari pasangan), (5) health of parent (terganggunya kondisi kesehatan pada orang tua itu sendiri).

Kemudian, adapun stres pengasuhan yang bersumber dari perilaku anak (Child Domain) meliputi (1) Child adaptability (kemampuan anak dalam beradaptasi dengan lingkungan), (2) Child demands (ketergantungan anak pada orang tua dalam beraktifitas), (3) Child mood (kerapnya kemunculan emosi negatif pada anak), (4) Distractability (sulit menaati dan menjalankan perintah pada anak). Selain itu, terdapat aspek stres pengasuhan yang bersumber dari interaksi orang tua-anak (Parent-child reletionship), yakni 
meliputi (1) Child reinforced parent (penguatan pada anak dan ibu), (2) Acceptabilty of Child to parent (penerimaan orang tua terhadap kondisi anak), (3) Attachment (kedekatan emosi antara orang tua dengan anak).

\section{Kualitas Pernikahan}

Secara konsep, kualitas pernikahan dapat diartikan sebagai kepuasan pernikahan, kesuksesan pernikahan, kebahagiaan pernikahan, penyesuaian pernikahan, stabilitas pernikahan, dan juga komitmen pernikahan. Karena secara operasional konsep-konsep tersebut masih mengandalkan evaluasi subjektif, konsep tersebut dipandang belum cukup menggambarkan kualitas pernikahan yang sesungguhnya. Namun terdapat pandangan dari Fowers dan Owenz yang lebih sesuai dengan mengedepankan aspek-aspek positif manusia tentang kebermaknaan dan kebaikan (Nurhayati \& Helmi, 2013).

Selain itu, dalam sebuah penelitian juga terdapat pendapat dari beberapa ahli mengenai definisi kualitas pernikahan, salah satunya adalah pendapat yang mengatakan bahwa kualitas pernikahan adalah sebuah ungkapan dari perasaan yang dirasakan oleh seseorang mengenai kondisi pernikahannya (Fowers \& Owens, 2010). Sedangkan Fincham dan Rogge berpendapat bahwa kualitas pernikahan adalah sebuah evaluasi subyektif individu secara keseluruhan tentang hubungan pernikahan (Fincham \& Rogge, 2010).

Ditinjau dari pernyataan di atas, dapat dikatakan bahwa kualitas pernikahan merupakan sebuah ungkapan rasa dari seorang individu mengenai baik atau buruknya kondisi pernikahan yang dia jalani bersama pasangan yang dimunculkan dalam bentuk perasaan dan tindakan.

Kualitas pernikahan memiliki Aspek yang terbagi menjadi dua, yaitu aspek positif dan aspek negatif (Allendorf \& Ghimire, 2013). Aspek Positif terdiri dari Kepuasan (adanya perasaan puas dan bahagia atas segala hal yang didapatkan dari hasil pernikahan), Komunikasi (tingkat kualitas komunikasi yang baik dengan pasangan), dan Kebersamaan (banyaknya waktu yang dihabiskan bersama pasangan dalam berbagai kegiatan). Sedangkan aspek negatif terdiri dari Masalah (ada-tidaknya persepsi bahwa pernikahan sedang dalam masalah) dan Ketidaksepakatan (kemunculan respon tidak setuju dalam berbagai kesepakatan).

\section{Kualitas Pernikahan dan Stres Pengasuhan}

Kualitas pernikahan merupakan aspek penting dari kehidupan keluarga yang membentuk kesejahteraan. Selain itu, kualitas pernikahan yang lebih banyak dikaitkan dengan rendahnya tingkat depresi, kesehatan diri sendiri yang lebih baik, penyakit fisik yang lebih sedikit, dan hasil positif lainnya. Kualitas pernikahan juga merupakan penentu penting dari perceraian. Secara luas, kualitas pernikahan adalah singkatan untuk kehadiran aspek-aspek bagus dari pernikahan dan yang ditandai dengan tidak adanya aspek buruk dalam rumah tangga (Allendorf \& Ghimire, 2013).

Aspek-aspek buruk yang terjadi dalam rumah tangga dapat menyebabkan proses pengasuhan orang tua pada anak menjadi terganggu dan kemudian meningkatkan tekanan saat proses pengasuhan tersebut sedang berlangsung, hingga pada akhirnya orang tua pun mengalami stres yang disebut stres pengasuhan. Stres pengasuhan sendiri adalah sebuah keadaan dimana terdapat ketegangan serta kecemasan berlebihan yang berasal dari interaksi dan peran pengasuhan anak yang sedang dijalankan oleh orang tua, hal tersebut terjadi karena adanya reaksi fisiologis dan kondisi psikologis yang tidak disenangi sebagai bentuk dari proses adaptasi dengan tuntutan peran dalam menjalankan tugas sebagai orang tua (Deckard, 2004).

Aspek-aspek buruk yang merupakan bentuk dari rendahnya kualitas pernikahan ini biasanya ditandai dengan kurangnya waktu yang dihabiskan bersama oleh kedua pasangan, kurangnya komunikasi untuk saling berbagi cerita dan keluh kesah dari kedua pasangan, serta adanya persepsi-persepsi tidak baik terhadap satu sama lain yang akhirnya menimbulkan emosi negatif yang dapat memperburuk kondisi psikologis saat sedang menjalankan tugas pengasuhan. Kemudian, buruknya kondisi psikologis yang disebabkan oleh rendahnya kualitas pernikahan tersebut mengakibatkan potensi munculnya tekanan menjadi semakin meningkat saat terjadi permasalahan atau hal-hal yang tidak diinginkan selama proses pengasuhan berlangsung, baik yang bersumber dari anak ataupun dari lingkungan sekitar (Mitchell et al., 2016).

Berdasarkan penjabaran diatas, dapat disimpulkan bahwa orang tua yang memiliki kualitas pernikahan yang baik dengan pasangannya akan menurunkan potensi terjadinya stres aki- 
bat proses pengasuhan anak. Namun bila orang tua memiliki kualitas pernikahan yang rendah, maka potensi terjadinya stres akibat proses pengasuhan anak akan semakin meningkat.

\section{METODE}

Penelitian ini adalah penelitian kuantitatif dengan desain korelasional yang berfungsi untuk mengetahui keberadaan hubungan antara variabel bebas dan variabel terikat yang digunakan di dalam penelitian ini, untuk kemudian diolah dengan teknik statistik dan dianalisis secara ilmiah (Sugiyono, 2012).

Sampel dalam penelitian ini diambil menggunakan teknik quota sampling, yaitu pengambilan sampel dari populasi dengan karakteristik tertentu yang dilakukan sampai jumlah kuota yang diinginkan telah terpenuhi (Sugiyono, 2012). Karakteristik subjek dalam penelitian ini adalah orang tua yang merupakan seorang ayah atau ibu yang masih memiliki pasangan (bukan orang tua tunggal) dan memiliki Anak Berkebutuhan Khusus. Sampel dalam penelitian ini berjumlah 80 orang, sesuai dengan pendapat yang mengatakan bahwa data penelitian dapat dikatakan normal apabila jumlah sampel pada penelitian mencapai 30 orang (Gravetter \& Wallnau, 2013).

Terdapat dua variabel dalam penelitian ini, yaitu Kualitas Pernikahan sebagai variabel bebas (Variabel X) dan Stres Pengasuhan sebagai variabel terikat (Variabel Y). Dimana Variabel terikat (stres pengasuhan) akan diukur menggunakan Parenting Stress Index (PSI), yaitu skala berjumlah 36 item yang diadaptasi dari skala stres pengasuhan milik Abidin (1995).

Sedangkan Variabel bebas (kualitas pernikahan) diukur menggunakan skala berjumlah 40 item yang dimodifikasi dari correlation matrix for marital quality factors dalam penelitian Allendorf \& Ghimire (2013), dimana matriks tersebut digunakan untuk mengetahui indikasi yang menggambarkan tinggi-rendahnya kualitas pernikahan dari pasangan suami-istri.

Alat ukur atau instrument dari stres pengasuhan dan kualitas pernikahan tersebut akan dikemas dalam bentuk skala likert, yaitu skala yang berfungsi untuk mengukur pendapat, persepsi, dan sikap individu mengenai suatu kejadian (Darmawan, 2013). Skala likert tersebut juga mengandung item berjenis Favorable dan Unfavorable dengan lima jawaban untuk setiap pernyataan, yaitu sangat sesuai, sesuai, ragu- ragu, tidak sesuai, dan sangat tidak sesuai.

Setiap jawaban yang ada dalam kedua skala tersebut akan mengandung skor yang berbeda-beda, yaitu sebagai berikut :

Favorable $\quad$ Sangat Sesuai $(\mathrm{SS})=5$; Sesuai $(\mathrm{S})=$ 4 ; Ragu-Ragu (R) = 3 ; Tidak Sesuai $(\mathrm{TS})=2$; Sangat Tidak Sesuai (STS) $=1$

Unfavorable : Sangat Sesuai $(\mathrm{SS})=1$; Sesuai $(\mathrm{S})=$ 2 ; Ragu-Ragu $(\mathrm{R})=3$; Tidak Sesuai $(\mathrm{TS})=4$; Sangat Tidak Sesuai (STS) $=5$

Penelitian ini memiliki 3 tahap, yaitu (1) Persiapan, (2) Pelaksanaan, dan (3) Analisis Data. Pada tahap pertama (persiapan), peneliti mempelajari teori-teori dari kedua variabel penelitian secara mendalam. Kemudian peneliti mencari dan menentukan skala yang sesuai dengan kedua variabel, serta melakukan proses pengujian skala terlebih dahulu agar nantinya skala tersebut layak digunakan untuk mengukur kedua variabel penelitian secara valid dan reliabel.

Pada tahap yang kedua (pelaksanaan), peneliti menyebarkan skala untuk diisi oleh para responden dengan karakteristik yang sudah ditentukan. Responden tersebut adalah orang tua yang masih memiliki pasangan (bukan orang tua tunggal) baik seorang Ayah ataupun Ibu yang memiliki Anak Berkebutuhan Khusus dari semua jenis dan usia. Target responden yang dicari oleh peneliti adalah minimal 30 orang.

Pada tahap ketiga (analisis data), peneliti melakukan analisa terhadap data dari skala yang telah disebar dan diisi oleh responden. Dimana semua data yang telah terkumpul akan diolah menggunakan sebuah program perhitungan statistik (SPSS 21) dengan metode analisis korelasi pearson yang bertujuan untuk menguji korelasi atau hubungan dari kedua variabel. Kemudian skor hasil analisis data diklasifikasikan menjadi 3 kategori dengan menggunakan norma kelompok.

Berdasarkan hasil uji validitas dan reliabilitas menggunakan teknik analisa faktor, pada skala stres pengasuhan terdapat 12 item yang tidak valid dan 24 item yang valid dengan rentang validitas $0.504-0,825$ serta nilai reliabilitas sebesar 0,906. Sedangkan pada skala kualitas pernikahan, terdapat 1 item yang dinyatakan tidak valid dan 39 item yang valid dengan rentang validitas $0.592-0.936$ disertai nilai reliabilitas sebesar 0,969 . 


\section{HASIL DAN PEMBAHASAN \\ Hasil}

Sebelum dilakukan analisis hipotesa, data harus terlebih dahulu diuji normalitasnya. Berdasarkan uji skewness-kurtosis, data dapat dikatakan normal apabila mencapai nilai skewness dan kurtosis tidak kurang dari -2 dan tidak lebih dari +2 . Oleh karena itu, data kedua variable dapat dikatakan normal karena telah mencapai nilai skewness sebesar -1,56 dan kurtosis sebesar 0,91 pada variabel $X$, serta skewness sebesar $-0,66$ dan kurtosis sebesar $-0,09$ pada variabel $Y$.

Dalam penelitian ini, subjek yang dicari adalah orang tua, yaitu seorang ayah atau ibu yang masih memiliki pasangan (bukan orang tua tunggal) dan memiliki anak berkebutuhan khusus (ABK). Dimana dalam penelitian ini terdapat 80 subjek dengan data sebagai berikut:

Tabel 1. Karakteristik Subjek Penelitian

\begin{tabular}{|c|c|c|c|c|}
\hline \multirow[b]{2}{*}{$\begin{array}{l}\text { Karakter- } \\
\text { istik }\end{array}$} & \multirow[b]{2}{*}{$\begin{array}{l}\text { Kate- } \\
\text { gori }\end{array}$} & \multicolumn{2}{|c|}{ Skor Rata-rata } & \multirow[b]{2}{*}{$\begin{array}{l}\text { Frekuen- } \\
\text { si }\end{array}$} \\
\hline & & $\begin{array}{c}\text { Kualitas } \\
\text { Pernikahan }\end{array}$ & $\begin{array}{c}\text { Stres } \\
\text { Pengasu- } \\
\text { han }\end{array}$ & \\
\hline \multirow{5}{*}{$\begin{array}{l}\text { Pendi- } \\
\text { dikan } \\
\text { Terakhir }\end{array}$} & $\mathrm{S} 1$ & 148 & 59,5 & 3 \\
\hline & D3 & 182 & 49 & 2 \\
\hline & SMA & 162 & 56 & 42 \\
\hline & SMP & 156 & 60 & 24 \\
\hline & $\mathrm{SD}$ & 160 & 61 & 9 \\
\hline \multirow{2}{*}{ Peran } & Ayah & 157 & 58 & 21 \\
\hline & Ibu & 161 & 58 & 59 \\
\hline Perbedaan & $1-5$ & & & \\
\hline Usia & Tahun & 160 & 57 & 62 \\
\hline $\begin{array}{l}\text { Subjek } \\
\text { dengan }\end{array}$ & $\begin{array}{c}\text { 6-10 } \\
\text { Tahun }\end{array}$ & 157 & 60 & 14 \\
\hline Pasangan & $\begin{array}{c}>10 \\
\text { Tahun }\end{array}$ & 163 & 51 & 4 \\
\hline \multirow{3}{*}{$\begin{array}{c}\text { Usia Per- } \\
\text { nikahan }\end{array}$} & $\begin{array}{c}\text { 1-10 } \\
\text { Tahun }\end{array}$ & 160 & 60 & 14 \\
\hline & $\begin{array}{l}\text { 10-20 } \\
\text { Tahun }\end{array}$ & 160 & 57 & 46 \\
\hline & $\begin{array}{c}>20 \\
\text { Tahun }\end{array}$ & 161 & 58 & 20 \\
\hline \multirow{2}{*}{$\begin{array}{c}\text { Usia } \\
\text { Ananda }\end{array}$} & $\begin{array}{c}\text { 1-10 } \\
\text { Tahun }\end{array}$ & 161 & 56 & 37 \\
\hline & $\begin{array}{c}>10 \\
\text { Tahun }\end{array}$ & 158 & 57 & 43 \\
\hline $\begin{array}{c}\text { Jenis } \\
\text { Kelamin }\end{array}$ & Pria & 162 & 56 & 50 \\
\hline Ananda & Wanita & 157 & 60 & 30 \\
\hline
\end{tabular}

\begin{tabular}{|c|c|c|c|c|}
\hline \multirow{1}{*}{ Jenis } & $\begin{array}{c}\text { Tuna } \\
\text { Grahita }\end{array}$ & 152 & 61 & 20 \\
\cline { 2 - 5 } & $\begin{array}{c}\text { Tuna } \\
\text { Rungu }\end{array}$ & 164 & 57 & 14 \\
\cline { 2 - 5 } Kebutuhan & $\begin{array}{c}\text { Tuna } \\
\text { Wicara }\end{array}$ & 160 & 55 & 17 \\
\cline { 2 - 5 } Ananda & $\begin{array}{c}\text { Tuna } \\
\text { Netra }\end{array}$ & 190 & 37 & 1 \\
\cline { 2 - 5 } & Autis & 160 & 58 & 13 \\
\cline { 2 - 5 } & ADHD & 170 & 57 & 9 \\
\cline { 2 - 5 } & $\begin{array}{c}\text { Sin- } \\
\text { drom } \\
\text { Down }\end{array}$ & 168 & 57 & 3 \\
\cline { 2 - 5 } & $\begin{array}{c}\text { Lambat } \\
\text { Belajar }\end{array}$ & 148 & 62 & 3 \\
\hline
\end{tabular}

Berdasarkan tabel diatas, dapat dilihat adanya beberapa karakteristik dengan kategori dan frekuensi yang beragam, yaitu, Pendidikan terakhir dengan kategori S1 yang berjumlah 3 orang $(3,75 \%)$, D3 yang berjumlah 2 orang $(2,5 \%)$, SMA yang berjumlah 42 orang $(52,5 \%)$, SMP yang berjumlah 24 orang (30\%), dan SD yang berjumlah 9 orang (11,25\%). Kemudian, karakteristik dengan kategori peran sebagai Ayah yang berjumlah 21 orang $(26,24 \%)$ dan Ibu yang berjumlah 59 orang (73,75\%). Selain itu, ada pula karakteristik mengenai perbedaan usia subjek dengan pasangan, yaitu kategori 1-5 tahun yang berjumlah 62 orang $(77,5 \%), 6-10$ tahun yang berjumlah 14 orang $(17,5 \%)$, dan lebih dari 10 tahun yang berjumlah 4 orang (5\%). Ada pula karakteristik tentang usia pernikahan subjek dengan pasangan, yaitu 1-10 tahun (14 orang / 17,5\%), 1020 tahun (46 orang / 57,5\%), dan diatas 20 tahun (20 orang / $25 \%$ ).

Tidak hanya itu, terdapat juga karakteristik tentang usia ananda (anak subjek) dengan kategori 1-10 tahun (37 orang / 46,25\%) dan diatas 10 tahun (43 orang / 53,75\%). Terdapat 50 subjek $(62,5 \%)$ yang memiliki anak laki-laki dan 30 subjek yang memiliki anak perempuan. Karakteristik terakhir mendapati 20 subjek (25\%) memiliki anak dengan Tuna Grahita, 14 subjek $(17,5 \%)$ memiliki anak dengan Tuna Rungu, 17 subjek $(21,25 \%)$ memiliki anak dengan Tuna Wicara, 1 subjek $(1,25 \%)$ memiliki anak dengan Tuna Netra, 13 subjek $(16,25 \%)$ memiliki anak dengan Autisme, 9 subjek $(12,5 \%)$ memiliki anak dengan ADHD, 3 subjek (3,75\%) memiliki anak dengan Down Syndrome, serta 3 subjek sisanya memiliki anak dengan lambat belajar.

Berdasarkan nilai rata-rata pada 80 subjek, stress pengasuhan dan kualitas pernikahan dibagi menjadi tiga kategori skor yang terdiri dari skor tinggi, sedang, dan rendah, yaitu sebagai berikut. 
Tabel 2. Kategorisasi Variabel

\begin{tabular}{cccc}
\hline & Rendah & Sedang & Tinggi \\
\hline Kualitas & Skor 39 & Skor 78 - & Skor 156 \\
Pernika- & -77 & 155 & -195 \\
$\quad$ han & & & \\
Frekuensi & 0 & 30 & 50 \\
Persentase & $0 \%$ & $37,5 \%$ & $62,5 \%$ \\
Stres Peng- & Skor 24 & Skor 48 & Skor $96-$ \\
asuhan & -47 & -95 & 120 \\
Frekuensi & 14 & 66 & 0 \\
Persentase & $17,5 \%$ & $82,5 \%$ & $0 \%$ \\
\hline
\end{tabular}

Berdasarkan table diatas, dapat dilihat bahwa subjek yang memiliki kualitas pernikahan yang Tinggi adalah 50 orang $(62,5 \%)$, sedangkan 30 orang $(37,5 \%)$ sisanya memiliki kualitas pernikahan di tingkat sedang. Pada variabel kedua, terdapat 14 orang $(17,5 \%)$ yang memiliki tingkat stres rendah dan 66 orang $(82,5 \%)$ yang memiliki tingkat stres sedang.

\section{Tabel 3. Hasil Uji Korelasi Product Moment} Pearson

\begin{tabular}{|c|c|c|c|}
\hline & & $\begin{array}{c}\text { Stres Pen- } \\
\text { gasuhan }\end{array}$ & $\begin{array}{c}\text { Kualitas } \\
\text { Pernikahan }\end{array}$ \\
\hline \multirow{3}{*}{$\begin{array}{l}\text { Stres Pen- } \\
\text { gasuhan }\end{array}$} & $\begin{array}{l}\text { Pearson } \\
\text { Correla- } \\
\text { tion }\end{array}$ & 1 &,$- 293^{* *}$ \\
\hline & $\begin{array}{l}\mathrm{S} \quad \mathrm{i} \quad \mathrm{g} \\
\text { (2-tailed) }\end{array}$ & & ,008 \\
\hline & $\mathrm{N}$ & 80 & 80 \\
\hline \multirow{3}{*}{$\begin{array}{l}\text { Kualitas } \\
\text { Pernikah- } \\
\text { an }\end{array}$} & $\begin{array}{l}\text { Pearson } \\
\text { Correla- } \\
\text { tion }\end{array}$ &,$- 293^{* *}$ & 1 \\
\hline & $\begin{array}{l}\mathrm{S} \text { i } \mathrm{g} \\
\text { (2-tailed) }\end{array}$ & ,008 & \\
\hline & $\mathrm{N}$ & 80 & 80 \\
\hline
\end{tabular}

Berdasarkan hasil uji korelasi diatas, dapat disimpulkan bahwa terdapat hubungan negatif yang signifikan antara kualitas pernikahan dan stress pengasuhan pada orang tua dengan anak berkebutuhan khusus. Tabel tersebut menunjukan bahwa orang tua dengan skor kualitas pernikahan yang tinggi ternyata memiliki skor rendah pada tingkat stres pengasuhan mereka.

\section{Pembahasan}

Berdasarkan penelitian yang dilakukan pada 80 subjek yang merupakan orang tua dengan anak berkebutuhan khusus, telah didapatkan hasil yang mengungkapkan bahwa kualitas pernikahan dan stres pengasuhan pada orang tua anak berkebutuhan khusus memiliki hubun- gan yang negatif dan signifikan. Ditandai dengan nilai koefisien korelasi ( $\mathrm{r}$ ) sebesar $\quad-0,293$ dan probabilitas (p) sebesar 0,008 . Hal tersebut mengartikan bahwa semakin tinggi kualitas pernikahan, maka semakin rendah tingkat stres pengasuhan yang akan dialami oleh orang tua dari anak berkebutuhan khusus. Sebaliknya, bila tingkat kualitas pernikahannya rendah, maka tingkat stres pengasuhan yang dapat dialami orang tua akan semakin tinggi.

Tingginya kualitas pernikahan ini biasanya ditandai dengan adanya dukungan, persepsi, komunikasi, dan interaksi yang baik antara suami dan istri, dimana hal tersebut dapat meningkatkan kepuasan pernikahan serta kebahagiaan pada kedua belah pihak. Hal tersebut sesuai dengan pendapat yang menyatakan bahwa dukungan dari pasangan dapat menjadi faktor yang memiliki pengaruh lebih besar terhadap kepuasan pernikahan dibandingkan dengan faktor gender atau yang lain (Ekas et al., 2015). Sehingga kebahagiaan tersebut akan berpengaruh pada emosi orang tua dalam menjalani tugas rumah tangga seperti mengasuh anak sehari-hari, dimana pasangan dapat menjadi motivasi, penyemangat, dan sumber bantuan untuk menyelesaikan segala permasalahan yang dapat menjadi penyebab terjadinya stres pengasuhan.

Adapun pendapat yang mendukung hasil tersebut, yaitu pendapat yang menyatakan bahwa jika satu pasangan tidak puas dengan pernikahan yang dijalaninya, mereka dapat bertindak negatif terhadap pasangan mereka dengan mengkritik atau menarik kasih sayang. Sebaliknya, orang yang bahagia dengan pernikahannya akan termotivasi untuk memberikan dukungan dan dorongan kepada pasangan mereka, sehingga meningkatkan kebahagiaan dan kesejahteraan emosional pasangan mereka (Carr et al., 2014).

Dengan demikian, kepuasan pernikahan pada pasangan suami-istri dapat mempengaruhi kesejahteraan emosional mereka (Carr et al., 2014). Yang dimaksud dengan kesejahteraan emosional pada proses pengasuhan ini adalah bentuk kehangatan dan kasih sayang terhadap anak, dimana kehangatan dan kasih sayang itu sendiri dapat dilihat dari seberapa sering orang tua menunjukkan cinta, kepedulian dan kasih sayangnya untuk sang anak, baik secara verbal maupun nonverbal (Rhee et al., 2015).

Bila memperhatikan salah satu tabel dari hasil penelitian, terlihat bahwa salah satu fak- 
tor yang mempengaruhi tingkat kualitas pernikahan dan stres pengasuhan adalah tingkat pendidikan orang tua. Dimana semakin tinggi pendidikan orang tua, maka semakin tinggi juga kualitas pernikahan mereka. Hal ini cukup sesuai dengan pendapat yang mengatakan bahwa durasi pernikahan dan pendidikan juga dapat memainkan peran tambahan dalam menentukan kualitas pernikahan sebuah pasangan (Allendorf \& Ghimire, 2013).

Mereka yang memiliki jenjang pendidikan lebih tinggi dan mereka yang telah menikah lebih lama memiliki tingkat kualitas pernikahan yang lebih tinggi. Sebaliknya, kasta, pekerjaan, usia saat menikah, dan jumlah anak tidak memiliki hubungan dengan kualitas pernikahan (Allendorf \& Ghimire, 2013). Adapun penelitian yang menemukan adanya penurunan kepuasan pernikahan dan peningkatan konflik pernikahan pada pasangan ibu dan ayah yang tidak menyelesaikan sekolah menengah, mereka yang memiliki pendidikan rendah cenderung kompetitif dan kurang dapat bekerjasama dengan pasangan sendiri (Christopher et al., 2015).

Kemudian, kualitas pernikahan yang baik dikerenakan tingginya jenjang sekolah orang tua dapat menjadi pengaruh dalam proses pengasuhan yang akhirnya dapat membuat tingkat stres orang tua menjadi lebih rendah. Hal tersebut dapat terjadi karena kualitas pernikahan yang baik dapat menyebabkan meningkatnya kehangatan dan komunikasi yang baik pula antara orang tua dengan anaknya. Selain itu, orang tua pun dapat menjadi stimulus dan pemberi toladan yang baik untuk sang anak, diikuti dengan meningkatnya dorongan belajar, penggunaan bahasa, serta pola interaksi yang baik antara orang tua dengan sang anak (Rizkillah, Sunarti, \& Herawati, 2015).

Pernyataan tersebut juga diperkuat dengan salah satu pendapat yang mengatakan bahwa pendidikan istri berhubungan positif dengan kualitas pernikahan yang pada akhirnya berpengaruh pada kualitas pengasuhan, yang berarti semakin tinggi pendidikan istri maka akan semakin baik kualitas pernikahannya dengan pasangan sehingga dapat meningkatkan kualitas lingkungan pengasuhan yang baik di dalam keluarga (Rizkillah, Sunarti, \& Herawati, 2015).

Terlepas dari faktor diatas, terdapat sebuah pendapat dari salah satu ahli yang mengatakann bahwa seorang ibu akan mengalami tingkat stres yang lebih tinggi dibandingkan dengan ayah dalam membesarkan anak-anak dengan kebutuhan khusus (Mcstay, Trembath, \& Dissanayake, 2014). Karena seorang ibu pasti akan mengalami sebuah tekanan apabila mendapati anaknya terlahir dengan kondisi perkembangan yang tidak sesuai harapan (Sa'diyah, 2016). Sayangnya, pernyataan tersebut kurang begitu sesuai dengan hasil analisa yang telah dilakukan oleh peneliti terhadap data dari seluruh responden. Karena bila dilihat dari hasil analisa dalam penelitian ini, terdapat bukti bahwa ayah dan ibu memiliki skor atau tingkat stres yang sama dalam proses mengasuh anak.

Tidak hanya itu, hasil analisa dalam penelitian ini juga menunjukan adanya faktor lain yang mempengaruhi tingkat kualitas pernikahan, yaitu perbedaan usia antara suami dan istri. Hasil analisa tersebut menggambarkan bahwa semakin jauh perbedaan usia antara pasangan, maka semakin tinggi kualitas pernikahannya. Selaras dengan hasil tersebut, adapun pendapat yang mengatakan bahwa perbedaan usia dengan pasangan atau kelayakan usia merupakan faktor penting dalam memiliki kehidupan pernikahan yang berkualitas. Dalam beberapa penelitian, terdapat pengaruh signifikan antara perbedaan usia terhadap kepuasan pernikahan. Biasanya direkomendasikan bahwa seorang wanita harus 2-4 tahun lebih muda dari seorang pria, bahkan perbedaan usia diatas 6-8 tahun dianggap tepat untuk memiliki kehidupan pernikahan yang baik (Zaheri et al., 2016).

Selain itu, ada pula kategori lain yang mempengaruhi perbedaan tingkat kualitas pernikahan dan stres pengasuhan orang tua pada hasil analisa diatas, yaitu usia pernikahan. Dimana hasil analisa tersebut menunjukan bahwa semakin lama usia pernikahan yang telah dijalani, maka semakin tinggi kualitas pernikahan yang mereka miliki. Sesuai dengan hal tersebut, terdapat pendapat yang mengatakan bahwa tahun-tahun awal pernikahan adalah masa yang rawan, bahkan juga dianggap sebagai masa kritis dalam suatu hubungan suami-istri karena keduanya sama-sama belum memiliki pengalaman yang cukup banyak (Anjani \& Suryanto, 2006).

Menurut hasil wawancara dalam sebuah penelitian terhadap masyarakat umum, terdapat alasan bahwa periode awal pernikahan merupakan era penyesuaian. Masa awal pernikahan adalah masa-masa yang dipenuhi dengan hal yang tak terduga, dimana di dalamnya terdapat 
banyak krisis dan berbagai masalah yang harus dihadapi, banyaknya perbedaan sikap dan perilaku masing-masing pasangan yang mulai terlihat. Selanjutnya akan timbul anggapan dari para pasangan bahwa pada masa awal pernikahan banyak muncul hal-hal yang tidak sesuai dengan harapan yang mereka pikirkan pada saat masih berpacaran (Anjani \& Suryanto, 2006).

Berdasarkan beberapa pemaparan yang telah dijelaskan diatas, dapat diambil pengertian bahwa kualitas pernikahan adalah salah satu faktor penting yang memiliki pengaruh besar terhadap tingkat stres pengasuhan pada orang tua yang memiliki anak berkebutuhan khusus. Disamping itu terdapat kelebihan dan kekurangan pada penelitian ini, sisi kelebihannya yakni merupakan salah satu penelitian dengan topik yang jarang dikaji oleh peneliti terdahulu. Selain terbilang memiliki topik yang cukup segar, hasil penelitian ini juga dapat memberikan informasi dan menambah pengetahuan peneliti maupun para orang tua mengenai kualitas pernikahan dan stres pengasuhan.

Selain itu, penelitian ini juga memiliki kekurangan, yaitu, penelitian ini belum memiliki sampel dengan cakupan jenis $\mathrm{ABK}$ yang merata, ditambah lagi diksi subjek yang digunakan dalam skala penelitian ini terlalu umum dan $\mathrm{ku}-$ rang terfokus pada orang tua $A B K$.

\section{KESIMPULAN DAN SARAN \\ Kesimpulan}

Berdasarkan hasil analisa dari penelitian yang telah dilakukan, dapat diambil kesimpulan bahwa kualitias pernikahan dan stres pengasuhan pada orang tua dengan anak berkebutuhan khusus memiliki hubungan negatif yang signifikan. Hasil penelitian ini menunjukan bahwa semakin tinggi kualitas pernikahan sepasang suami-istri, maka akan semakin rendah tingkat stres pengasuhan yang mereka rasakan. Disamping itu, dari penelitian ini juga didapatkan temuan-temuan lain yang menunjukan bahwa kualitas pernikahan dapat dipengaruhi oleh beberapa faktor penting seperti tingkat pendidikan orang tua, perbedaan usia pada suami dan istri, dan usia pernikahan. Oleh karena itu, diharapkan untuk para orang tua di luar sana agar dapat menjaga hubungan baik dengan suami demi terjalinnya kualitas pernikahan yang baik sehingga dapat meminimalisir terjadinya stres karena proses pengasuhan anak sehari-hari.

\section{Saran}

Saran untuk peneliti selanjutnya yang mungkin akan mengambil topik yang sama, penelitian ini tentu dapat dikembangkan ataupun menjadi bahan referensi. Namun alangkah baiknya apabila peneliti berikutnya dapat memperluas pengambilan sampel dengan lebih merata, terutama pada kategori jenis kebutuhan anak dari para orang tua yang akan dijadikan sampel.

\section{REFERENSI}

Abidin, R. R. (1995). Parenting stress index third edition: Professional manual. Lutz, FL: Psychological Assessment Resources, Inc.

Abidin, R. R. (2010). The determinants of parenting behavior. Journal of Clinical Child Psychology, 21(4), 37-41. https://doi. org/10.1207/s15374424jccp2104_12

Allendorf, K., \& Ghimire, D. J. (2013). Determinants of marital quality in an arranged marriage society. Social Science Research, 42(1), 59-70. https://doi.org/10.1016/j.ssresearch.2012.09.002

Anjani, C., \& Suryanto. (2006). Pola penyesuaian pernikahan pada periode awal. INSAN, 8(3), 198-210.

Carr, D., Freedman, V. A., Cornman, J. C., \& Consulting, J. C. C. (2014). Happy marriage , happy life ? Marital quality and subjective well-being in later life. Journal of Mariage and Family, 76(October), 930-948. https:// doi.org/10.1111/jomf.12133

Christopher, C., Umemura, T., Mann, T., Jacobvitz, D., Hazen, N., \& Christopher, C. (2015). Marital quality over the transition to parenthood as a predictor of coparenting spouses function as partners or adversaries in their. Journal of Child and Family Studies. https://doi.org/10.1007/s10826-015-0172-0

Darmawan, D. (2013). Metode penelitian kuantitatif. (D. Darmawan, Ed.). Bandung: PT Remaja Rosdakarya.

Deckard, D. (2004). Parenting stress: Current perspective in psychology. New Haven: Yale University Press.

Ekas, N. V, Timmons, L., Pruitt, M., Ghilain, C., \& Alessandri, M. (2015). The power of positivity : Predictors of relationship satisfaction for parents of children with autism spectrum disorder. Journal of Autism and Developmental Disorders. https://doi. 
org/10.1007/s10803-015-2362-4

Fincham, F. D., \& Rogge, R. (2010). Understanding relationship quality : Theoretical challenges and new tools for assessment. Journal of Family Theory \& Review, 2, 227-242. https://doi.org/10.1111/j.17562589.2010.00059.x

Firmansyah, Sukirno, \& Sudaryatmi, S. (2017). Kedudukan anak dalam pernikahan adat ngerorod (kawin lari) di desa padang sambilan kaja, kecamatan denpasar barat, denpasar, 6, 1-12.

Fowers, B. J., \& Meghan B. Owens. (2010). A eudaimonic theory of marital quality. Journal of Family Theory E Review, 2, 334-352. https:// doi.org/10.1111/j.1756-2589.2010.00065.x

Gravetter, F. J., \& Wallnau, L. B. (2013). Statistics for the behavioral scienes. (T. Matray, Ed.) (9th ed.). New York: Jon-David Hague.

Harper, A., \& Dyches, T. T. (2013). Respite care , marital quality, and stress in parents of children with autism spectrum disorders. Journal of Autism and Developmental Disorders. https://doi.org/10.1007/s10803-0131812-0

Hsiao, Y. J. (2017). Parental stress in families of children with disabilities. Intervention in School and Clinic, 53(4), 201-205. https://doi. org/10.1177/1053451217712956

https://kbbi.web.id/kualitas. diakses pada 13 November 2018

Ilias, K., Cornish, K., Kummar, A. S., Park, M. S., \& Golden, K. J. (2018). Parenting stress and resilience in parents of children with autism spectrum disorder (ASD) in southeast asia : A systematic review. Systematic Review, 9. https://doi.org/10.3389/ fpsyg.2018.00280

Santoso, Imam Sigit. (2017). Tradisi nolong cece'an dalam pernikahan perspektif 'urf. Malang: Fakultas Syari'ah Universitas Islam Negeri.

Johnston, C., Hessl, D., Blasey, C., Eliez, S., Erba, H., Dyer-Friedman, J., ... Reiss, A. L. (2003). Factors associated with parenting stress in mothers of children with fragile $X$ syndrome. Journal of Developmental and Behavioral Pediatrics, 24(4), 267-275.
Krakovich, T. M., Mcgrew, J. H., Yu, Y., \& Ruble, L. A. (2016). Stress in parents of children with autism spectrum disorder : an exploration of demands and resources. Journal of Autism and Developmental Disorders, 46(6), 2042-2053. https://doi. org/10.1007/s10803-016-2728-2

Mcstay, R. L., Trembath, D., \& Dissanayake, C. (2014). Stress and family quality of life in parents of children with autism spectrum disorder : Parent gender and the double abcx model. https://doi.org/10.1007/s10803014-2178-7

Mitchell, D. B., Szczerepa, A., \& Hauser-cram, P. (2016). Research in developmental disabilities spilling over : partner parenting stress as a predictor of family cohesion in parents of adolescents with developmental disabilities. Research in Developmental Disabilities, 50, 49-50. https://doi.org/http:// dx.doi.org/10.1016/j.ridd.2015.12.007

Nurhayati, S. R., \& Helmi, A. F. (2013). Marital flourishing : Kualitas pernikahan dalam teori eudaimonik. Buletin Psikologi, 21(2), 68-79.

Pramudito, Achmad. (2015). Tak kompak, anak autis bisa jadi pemicu perceraian. Surabaya.tribunnews.com. diakses pada 10 April 2019

Rhee, K. E., Dickstein, S., Jelalian, E., Boutelle, K., Seifer, R., \& Wing, R. (2015). Development of the general parenting observational scale to assess parenting during family meals. Journal of Behavioral Nutrition and Physical Activity, 12-49. https://doi. org/10.1186/s12966-015-0207-3

Rizkillah, R., Sunarti, E., \& Herawati, T. (2015). Marital and parenting environment quality of dual earner family abstract, 8(1), 10-19.

Sa'diyah, S. (2016). Gambaran psychological well-being dan stres pengasuhan ibu dengan anak autis. Psychology and Humanity, 19-20.

Sinha, D., Verma, N., \& Hershe, D. (2016). A comparative study of parenting styles, parental stress and resilience among parents of children having autism spectrum disorder, parents of children having specific learning disorder and parents of children not diagnosed with any psychiatric disorder. Annals of International Medical and Dental Research, 2(4), 106-110. https://doi. org/10.21276/aimdr.2016.2.4.30 